\title{
ЗМІНИ ПРОЦЕСІВ ЕНЕРГОЗАБЕЗПЕЧЕННЯ НЕЙТРОФІЛІВ КРОВІ В ЩУРІВ 3 ПАРОДОНТИТОМ НА ТЛІ ГІПЕР- ТА ГІПОТИРЕОЗУ
}

Вступ. Запальні захворювання пародонта є однією з найактуальніших проблем стоматології, які мають соціальну значимість. Поряд з відомими концепціями їх патогенезу значну увагу приділяють активації пероксидного окиснення ліпідів, що може порушувати окиснення субстратів дегідрогеназами і транспорт електронів по дихальному ланцюгу, спричиняючи роз'єднання дихання та окисного фросфорилювання.

Мета дослідження - вивчити процеси енергозабезпечення нейтрофрілів крові в щурів з пародонтитом без супутньої патології і на тлі гіпер- та гіпотиреозу.

Методи дослідження. Дослідження проведено на білих щурах-самцях, в яких моделювали пародонтит, пародонтит на тлі гіпертиреозу та пародонтит на тлі гіпотиреозу. В мітохондріальній фрракції популяції нейтрофрілів крові визначали сукцинатдегідрогеназну та цитохромоксидазну активність. Кількість нейтрофрілів крові зі зниженим трансмембранним мітохондріальним потенціалом встановлювали методом проточної цитофрлуориметрії за допомогою набору реактивів "MitoScreen" ("BD Pharmigen", США).

Результати й обговорення. Сукцинатдегідрогеназна активність у мітохондріях нейтрофрілів крові щурів із змодельованим пародонтитом зменшилася на 16,3 \% (p<0,001), із змодельованим пародонтитом на тлі гіпертиреозу - на 40 \% (p<0,001), із змодельованим пародонтитом на тлі гіпотиреозу - на 26,7 \% $(p<0,001)$ відносно контрольної групи. Що стосується кінцевого ензиму дихального ланцюга мітохондрій цитохромоксидази, то за умови пародонтиту без супутньої патології його активність у мітохондріях нейтрофрілів крові тварин достовірно не змінилася. Експериментальний пародонтит на тлі гіпертиреозу супроводжувався зниженням цитохромоксидазної активності на 15,2 \% ( $p<0,01)$, а в гіпотиреоїдних щурів - на 16,2 \% (р<0,001) відносно контрольної групи. Дослідження мітохондріального трансмембранного потенціалу $(\Delta \Psi \mathrm{m})$ нейтрофрілів крові показало, що у тварин із змодельованим пародонтитом відсо-

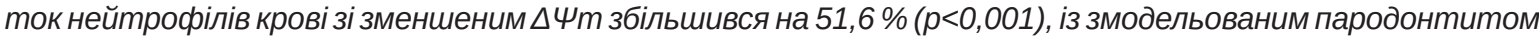
на тлі гіпертиреозу - в 2,4 раза (p<0,001), із змодельованим пародонтитом на тлі гіпотиреозу - в 1,8 раза $(p<0,001)$ щодо контрольної групи.

Висновок. Моделювання пародонтиту на тлі тиреоїдної дисфункції супроводжується достовірним інгібуванням процесів енергозабезпечувального окиснення, на що вказує зниження сукцинатдегідрогеназної та цитохромоксидазної активності в мітохондріях нейтрофрілів крові як за умови гіпертиреозу, так $і$ при гіпотиреозі.

КЛЮчОВІ СЛОВА: пародонтит; енергозабезпечувальне окиснення; тиреоїдна дисфункція.

ВСТУП. Запальні захворювання пародонта $€$ однією 3 найактуальніших проблем стоматології, які мають соціальну значимість, що зумовлено високою розповсюдженістю, вираженими змінами в тканинах пародонта й організму хворого в цілому, ураженням осіб молодого віку [1]. Багато років існує тенденція до більш раннього виникнення даного захворювання і його агресивного перебігу [2].

В останні роки поряд з відомими концепціями патогенезу запальних і запально-дистрофрічних захворювань пародонта значну увагу приділяють активації пероксидного окиснення ліпідів.

(c) В. В. Щерба, Т. Я. Ярошенко, І. А. Бандас, М. М. Корда, 2019.
Відомо, що неконтрольовані реакції пероксидного окиснення ліпідів здатні не тільки призводити до порушення обмінних процесів, а й викликати структурні зміни в тканинах, пригнічувати захисні механізми організму, що, у свою чергу, сприяє активації мікробів, які колонізують ясна і пародонтальні кишені [3, 4]. Токсичні метаболіти, а також продукти ініційованої ними ліпопероксидації порушують окиснення субстратів дегідрогеназами, транспорт електронів по дихальному ланцюгу, спричиняючи роз'єднання дихання та окисного фоосфорилювання. Незворотні порушення у структурі та фрункціонуванні мітохондрій, викликані дією надмірної кількості активних фором оксигену (АФО), зумовлюють зсув 
енергетичного метаболізму в бік зростання інтенсивності гліколізу та пригнічення окисного фросорорилювання [5, 6].

Мета дослідження - вивчити процеси енергозабезпечення нейтрофрілів крові в щурів з пародонтитом без супутньої патології і на тлі гіперта гіпотиреозу.

МЕТОДИ ДОСЛІДЖЕННЯ. Дослідження проведено на 48 безпородних статевозрілих білих щурах-самцях масою 180-200 г, яких утримували на стандартному раціоні віварію.

Піддослідних тварин було поділено на 4 групи. До 1-ї групи входили контрольні щури, яким вводили внутрішньошлунково 1 \% розчин крохмалю (n=12). Тварини з моделлю пародонтиту становили 2-гу групу. Протягом 2-х тижнів через день їм вводили в тканини ясен по 40 мікролітрів (1 мг/мл) ліпополісахариду (ЛПС) E. coli ("SigmaAldrich", США) (n=12) [7]. Щури з пародонтитом на тлі гіпертиреозу складали 3-тю групу. Для моделювання експериментальної гіпердункції щитоподібної залози тваринам щоденно внутрішньошлунково вводили L-тироксин на $1 \%$ розчині крохмалю з розрахунку 10 мкг/добу на 100 г маси впродовж 21-ї доби ( $\mathrm{n=12}$ [8]. Починаючи з 8-ї доби експерименту, їм вводили в тканини ясен ЛПС протягом 2-х тижнів. До 4-ї групи входили щури з пародонтитом на тлі гіпотиреозу. 3 метою моделювання експериментальної гіпофункції щитоподібної залози тваринам щоденно внутрішньошлунково вводили мерказоліл на 1 \% розчині крохмалю з розрахунку 1 мг/добу на 100 г маси впродовж 21-ї доби (n=12) [8]. Починаючи з 8-ї доби експерименту, їм вводили в тканини ясен ЛПС протягом 2-х тижнів. Евтаназію щурів здійснювали шляхом кровопускання за умов тіопентал-натрієвого наркозу на 22-гу добу від початку досліду.

Усі маніпуляції з експериментальними тваринами проводили, дотримуючись правил відповідно до Європейської конвенції про захист хребетних тварин, що використовуються для дослідних та інших наукових цілей [9].

Популяцію нейтрофрілів крові отримували за допомогою центрифугування на подвійному градієнті щільності 1,077 і 1,093 фріколу-верографріну [10]. Для виділення мітохондріальної фрракції популяцію нейтрофрілів ресуспендували 3 5-ма об'ємами бусрера, що містив 0,25 М сахарозу, 10 мМ фросфат калію, 1 мМ ЕДТА (pH 7,2). Суспензію клітин гомогенізували. Гомогенат центрифугували при 800 g протягом 10 хв. Осад центрифугували при 8000 g упродовж 10 хв на центрифузі з охолодженням HERMLE Z 32 HK і ресуспендували з бусрером без ЕДТА [11]. Сукцинатдегідрогеназну активність визначали згідно
3 методом [12], принцип якого полягає у відновленні фрериціаніду калію до фрероціаніду калію сукцинатом з участю ензиму, цитохромоксидазну - за реакцією окиснення диметил-n-френілендіаміну [13]. Кількість нейтрофрілів крові зі зниженим трансмембранним мітохондріальним потенціалом встановлювали методом проточної цитофрлуориметрії за допомогою набору реактивів "MitoScreen" ("BD Pharmigen”, США), ключовим реагентом якого є фрлуорохром 5,5',6,6'-тетрахлоро-1,1',3,3'тетраетилбензимідазоліл карбоціаніну йодид [14].

Статистичну обробку цисррових даних здійснювали за допомогою програмного забезпечення Excel ("Microsoft", США) і STATISTICA 6.0 ("Statsoft", США) з використанням параметричних методів оцінки отриманих даних. Для всіх показників розраховували значення середньої арисрметичної вибірки (М), її дисперсії і помилки середньої (m). Вірогідність різниці значень між незалежними кількісними величинами визначали за t-критерієм Стьюдента (вірогідними вважали відмінності при р<0,05).

РЕЗУЛЬТАТИЙ ОБГОВОРЕННЯ. МеТаболічні перетворення, що відбуваються в лейкоцитах периорерійної крові, відображають стан обмінних і регуляторних процесів в організмі [15]. Мітохондріальні дисфункції, пов'язані 3 процесами окисного фроссрорилювання, структурною цілісністю мітохондрій та інфрормаційною ідентичністю їх генетичного апарату, виникають за умов оксидативного стресу, при хворобах, викликаних метаболічними порушеннями, а також канцерогенезі [16]. Саме дихальний ланцюг мітохондрій $€$ основним внутрішньоклітинним джерелом генерації АФО, а активність сукцинатдегідрогенази як компонента II комплексу дихального ланцюга значною мірою визначає швидкість використання оксигену і синтезу АТФ у мітохондріях [11].

Сукцинатдегідрогеназна активність у мітохондріях нейтрофрілів крові щурів із змодельованим пародонтитом знизилася на 16,3 \% ( $<<0,001)$ відносно контрольної групи (табл.). У тварин із змодельованим пародонтитом на тлі гіпертиреозу вона зменшилася на $40 \%(p<0,001)$ відносно контрольної групи. При цьому сукцинатдегідрогеназна активність у мітохондріях нейтросрілів крові гіпертиреоїдних щурів на 28,4 \% достовірно була нижчою від даного показника за умови пародонтиту без супутньої патології та на 18,2 \% (p<0,001) - при пародонтиті на тлі гіпотиреозу (рис. 1). У тварин із змодельованим пародонтитом на тлі гіпотиреозу вона також достовірно зменшилася - на 26,7 \% відносно контрольної групи, будучи нижчою від даного 
Таблиця - Показники енергозабезпечувального окиснення в мітохондріях нейтрофілів крові щурів

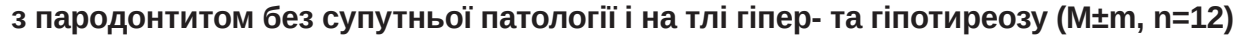

\begin{tabular}{|c|c|c|c|c|}
\hline \multirow[b]{2}{*}{ Показник } & \multicolumn{4}{|c|}{ Група тварин } \\
\hline & контрольна & пародонтит & $\begin{array}{l}\text { пародонтит на тлі } \\
\text { гіпертиреозу }\end{array}$ & $\begin{array}{c}\text { пародонтит на тлі } \\
\text { гіпотиреозу }\end{array}$ \\
\hline $\begin{array}{l}\text { Сукцинатдегідроге- } \\
\text { назна активність, } \\
\text { нмоль/(мг×хв) }\end{array}$ & $2,40 \pm 0,07$ & $\begin{array}{c}2,01 \pm 0,07 \\
p_{1}<0,002\end{array}$ & $\begin{array}{c}1,44 \pm 0,04 \\
p_{1}<0,001 \\
p_{2}<0,001\end{array}$ & $\begin{array}{c}1,76 \pm 0,05 \\
p_{1}<0,001 \\
p_{3}<0,02 \\
p_{4}<0,001\end{array}$ \\
\hline $\begin{array}{l}\text { Цитохромоксидазна } \\
\text { активність, } \\
\text { нмоль/(мг×хв) }\end{array}$ & $1,91 \pm 0,06$ & $\begin{array}{c}1,79 \pm 0,04 \\
p_{1}>0,05\end{array}$ & $\begin{array}{c}1,62 \pm 0,06 \\
p_{1}<0,01 \\
p_{2}<0,05\end{array}$ & $\begin{array}{c}1,60 \pm 0,03 \\
p_{1}<0,001 \\
p_{3}<0,01 \\
p_{4}>0,05\end{array}$ \\
\hline
\end{tabular}

Примітки

1. $p_{1}$ - достовірність відмінностей між контрольною і дослідними групами.

2. $p_{2}$ - достовірність відмінностей між групою щурів з пародонтитом і групою тварин з пародонтитом на тлі гіпертиреозу.

3. $p_{3}$ - достовірність відмінностей між групою щурів з пародонтитом і групою тварин з пародонтитом на тлі гіпотиреозу.

4. $\mathrm{p}_{4}$ - достовірність відмінностей між групою щурів з пародонтитом на тлі гіпертиреозу і групою тварин 3 пародонтитом на тлі гіпотиреозу.

показника на 12,4 \% ( $<<0,02)$ щодо щурів 3 пародонтитом без супутньої патології.

Дещо інші зміни зафріксовано стосовно кінцевого ензиму дихального ланцюга мітохондрій - цитохромоксидази, що, як і сукцинатдегідрогеназа, визначає фрункціонування ланцюга перетворень енергетичних субстратів [17]. За умови пародонтиту без супутньої патології іiї активність у мітохондріях нейтрофрілів крові щурів зменшилася на 6,3 \% відносно контрольної групи, але зміни виявилися недостовірними. Експериментальний пародонтит на тлі гіпертиреозу супроводжувався більш вираженим зниженням цитохромоксидазної активності (на 15,2 \%, p<0,01) відносно контрольної групи, що на 9,5\% $(p<0,05)$ менше від цього показника за умови пародонтиту без супутньої патології (рис. 2). У щурів із змодельованим пародонтитом на тлі гіпотиреозу цитохромоксидазна активність також достовірно зменшилася - на 16,2 \% відносно контрольної групи, будучи нижчою від даного показника на 10,6 \% (p<0,01) щодо тварин

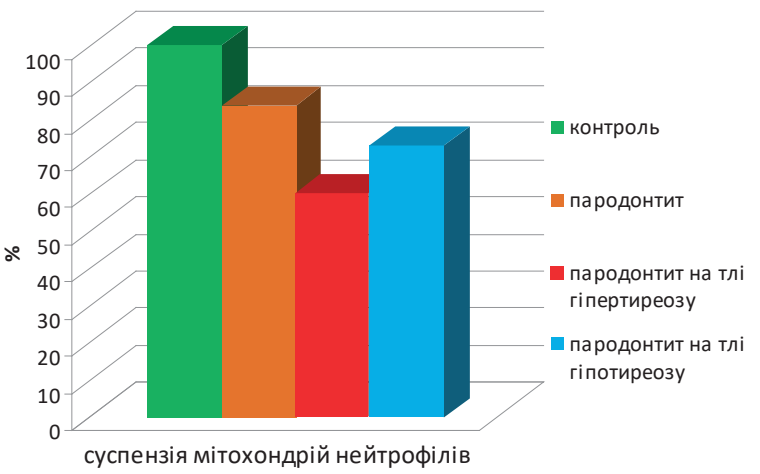

Рис. 1. Зміни сукцинатдегідрогеназної активності в мітохондріях нейтрофілів крові за умови пародонтиту на тлі тиреоїдної дисфункції у відсотках.
3 пародонтитом без супутньої патології. Варто вказати, що цитохромоксидазна активність у мітохондріях нейтрофрілів крові щурів із пародонтитом на тлі гіпертиреозу та пародонтитом на тлі гіпотиреозу виявилася практично ідентичною.

Отже, інтенсивність процесів енергозабезпечення за умови пародонтиту на тлі тиреоїдної диссрункції достовірно знижується, що в кінцевому результаті призводить до "енергетичного голоду". Багато дослідників відзначає складні зв'язки між ефектами тиреоїдних гормонів і функцією мітохондрій. Так, S. Vidali та співавт. зазначають, що гормони щитоподібної залози діють як ключові регулятори енергетичного обміну людини і стимулюють мітохондріальну активність та біогенез у різних органах [18]. Крім того, тиреоїдні гормони, впливаючи на експресію генів, змінюють активність багатьох ензимних систем, у тому числі й мітохондріальних [19].

Тироксин пригнічує малатдегідрогеназу і може перешкоджати, таким чином, синтезу оксалоацетату, який пригнічує сукцинатдегідрогена-

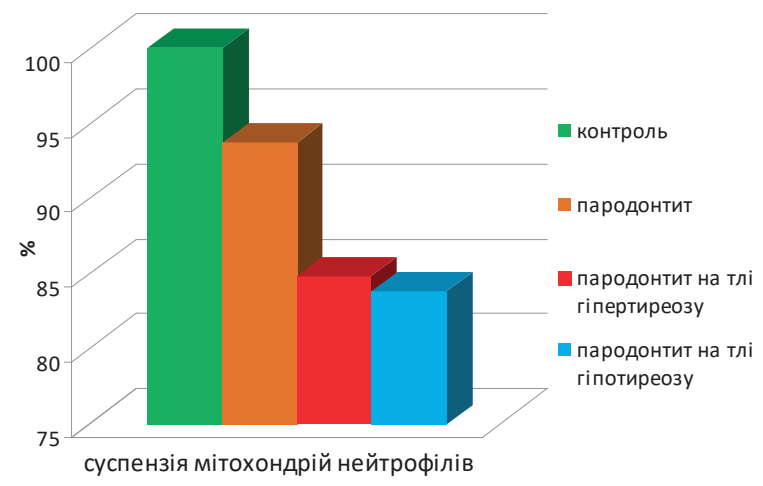

Рис. 2. Зміни цитохромоксидазної активності в мітохондріях нейтрофрілів крові за умови пародонтиту на тлі тиреоїдної дисфуункції у відсотках. 
зу [20]. Цикл трикарбонових кислот контролюють концентрація субстратів, співвідношення АТФ/ АДФ, окисно-відновний стан коензимів, а також швидкість транспорту інтермедіантів через мітохондріальні мембрани. Під час обговорення механізмів змін активності ензимів за умови гіпотиреозу на перший план виступає анаболічний ефект тиреоїдних гормонів - контроль ними протеїносинтезувального апарату клітини. Необхідно також врахувати й алостеричний контроль - вплив на активність дегідрогеназ енергетичного обміну співвідношень НАД $/ \mathrm{HАДН,}$ АДФ/АТФ [21]. Крім того, зниження енергозабезпечувального окиснення за умови тиреоїдної дисфункції, ймовірно, можна пояснити підвищенням продукування АФО в мітохондріях, що призводить до ушкодження електронотранспортного ланцюга, до зменшення синтезу АТФ і пов'язаного з цим зниження активності АТФ-залежних ензимів [22].

Окрім відомої енергетичної функції, яку раніше вважали основною для мітохондрій, ці органели не лише приймають та координують проапоптотичні сигнали, але і самі виробляють їх. При цьому окиснені субстрати мітохондрії використовують для фрормування мембранного потенціалу у вигляді протонного градієнта на їх внутрішній мембрані [23]. Трансмембранний потенціал може характеризувати як функцію мітохондрій, так і стан усієї клітини [24]. Зміни трансмембранного потенціалу та вивільнення 3 міжмембранного простору мітохондрій проапоптичних фракторів знижують електрохімічний градієнт протонів, який створюється на внутрішній мембрані мітохондрій ланцюгом перенесення електронів, що, з одного боку, викликає в клітинах зменшення швидкості утворення АТФ так званий "енергетичний голод", а з іншого посилює перехід електронів на оксиген, тим самим підвищуючи кількість внутрішньоклітинних АФО [6, 25, 26]. Змінені в результаті впливу АФО молекули можна вважати сигналами, які несуть біологічну інфрормацію, необхідну для регуляції різних клітинних фуннцій, зокрема реалізації апоптозу [27].

Наші дослідження мітохондріального трансмембранного потенціалу $(\Delta \Psi \mathrm{m})$ нейтрофрілів крові показали, що в щурів із змодельованим пародонтитом відсоток нейтрофрілів крові зі зниженим $\Delta \Psi_{\mathrm{m}}(1,94 \pm 0,09)$ збільшився на 51,6 \% $(p<0,001)$ відносно контрольної групи $(1,28 \pm 0,09)$. У тварин із змодельованим пародонтитом на тлі гіпертиреозу цей показник $(3,08 \pm 0,10)$ зріс у 2,4 раза $(p<0,001)$ щодо контрольної групи. Варто вказати, що відсоток нейтрофрілів крові зі зменшеним $\Delta \Psi \mathrm{m}$ у гіпертиреоїдних щурів на 58,8 \% достовірно перевищував величину дано- го показника за умови пародонтиту без супутньої патології та на 31,1 \% ( $<<0,002)$ - при пародонтиті на тлі гіпотиреозу. При цьому у тварин із змодельованим пародонтитом на тлі гіпотиреозу відсоток нейтрофрілів крові зі зниженим $\Delta \Psi \mathrm{m}$ $(2,35 \pm 0,11)$ також достовірно зріс - в 1,8 раза відносно контрольної групи, перевищуючи величину даного показника на 21,1 \% ( $<<0,01)$ відносно щурів з пародонтитом без супутньої патології (рис. 3).

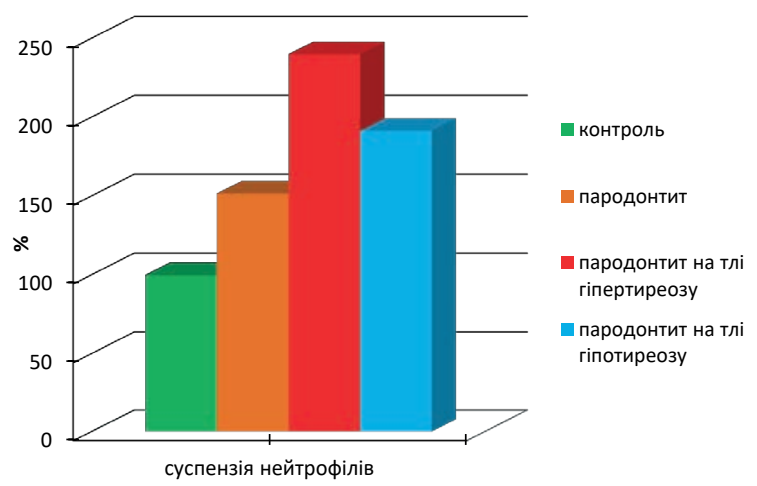

Рис. 3. Зміни кількості нейтрофрілів крові зі зниженим трансмембранним потенціалом за умови пародонтиту на тлі тиреоїдної диссуункції у відсотках.

Тиреоїдний статус впливає на проникність мітохондріальної мембрани. За умови гіпертиреозу вона більш проникна для іонів кальцію, ніж при гіпотиреозі [28]. У результаті цього відбувається деполяризація мембрани клітин, підвищується інтенсивність іонних потоків через мембрану і посилюється масове надходження $\mathrm{Ca}^{2+}$ у внутрішній простір мітохондрій, що запускає каскад внутрішньоклітинних катаболічних реакцій. Внаслідок нестачі АТФ порушується також робота Са-насоса, що відкачує $\mathrm{Ca}^{2+} 3$ клітини. Внутрішньоклітинне накопичення $\mathrm{Ca}^{2+}$ викликає перевантаження мітохондрій з роз'єднанням окисного фоссрорилювання та їх набуханням. Крім того, гіперпродукування АФО та збільшення $\mathrm{Ca}^{2+}$ в мітохондріях призводять до активації сроссроліпаз, які відщеплюють жирні кислоти від фоссроліпідів. Відомо, що жирні кислоти спричиняють роз'єднання окисного фоссрорилювання, що характеризується набуханням мітохондрій, зміною проникності мітохондріальної мембрани з утворенням мітохондріальної пори [22, 29]. Гіпотиреоз впливає на експресію мітохондріальних протеїнів з дихального ланцюга. У зв'язку з цим, було показано, що рівень коензиму Q10 знижується, як і зменшується антиоксидантна ємність мітохондрій [30].

ВИСНОВОК. Моделювання пародонтиту на тлі тиреоїдної дисфрункції супроводжується достовірним інгібуванням процесів енергозабезпе- 
чувального окиснення, на що вказує зниження сукцинатдегідрогеназної та цитохромоксидазної активності в мітохондріях нейтрофрілів крові як за умови гіпертиреозу, так і при гіпотиреозі.

\section{СПИСОК ЛІТЕРАТУРИ}

1. Сакварелидзе И. Роль свободно-радикального окисления и антиоксидантной защиты в развитии воспалительных процессов в пародонте в женской популяции / И. Сакварелидзе // Актуальные Вопросы Женского Здоровья. - 2014. - № 5. - С. 64-76.

2. Успенская О. А. Изменения биохимических показателей крови при лечении быстропрогрессирующего пародонтита / О. А. Успенская, Е. С. Качесова // Проблемы стоматологии. -2017. - № 13 (2). - С. 33-38.

3. Савельева Н. Н. Состояние системы перекисного окисления липидов и антиоксидантной защиты у больных хроническим генерализованным пародонтитом I-II степени тяжести, сочетающегося с паразитозами / Н. Н. Савельева // Journal of Education, Health and Sport. - 2015. - № 5 (12). - C. 465-476.

4. Almerich-Silla J.M. Oxidative stress parameters in saliva and its association with periodontal disease and types of bacteria / J.M. Almerich-Silla, J.M. MontielCompany, S. Pastor, F. Serrano, M. Puig-Silla, F. Dasi // Dis. Markers. - 2015. - Article ID 653537.

5. Лихацький П. Г. Динаміка змін маркерів біоенергетичних процесів та цитолізу у щурів після ураження нітритом натрію на тлі тютюнової інтоксикації / П. Г. Лихацький, Л. С. Фіра, Я. І. Гонський // Вісн. проблем біології і медицини. -2017. - №2 (136). - С. 147-152.

6 . Rutska A.V. The changes of bioenergetics processes in rats of different sex and age in case of tobacco smoke and monosodium glutamate affection / A. V. Rutska, I.Ya. Krynytska // International Journal of Medicine and Medical Research. - 2018. - No. 2 (4). - P. 79-86.

7. Моисеева Е. Г. Метаболический гомеостаз и имунная реактивность организма в динамике воспаления в тканях пародонта (экспериментальное исследование) : автореф. дисс. на соискание учен. степени д-ра мед. наук / Е. Г. Моисеева. - М., 2008. - 45 с.

8. Ратушненко В. О. Функціональна роль тіол-дисульфрідної системи при експериментальному гіпо- i гіпертиреозі / В. О. Ратушненко // Одес. мед. журн. 2010. - № 2 (118). - C. 17-20.

9. European convention for the protection of vertebrate animals used for experimental and other scientific purposes. - Council of Europe. Strasbourg. - 1986. No. 23. - P. 52.

10. Кисеньзалежні фрункції фрагоцитів у хворих на хронічне обструктивне захворювання легень / $€$. М. Нейко, П. Р. Герич, М. М. Островський, Л. М. Томащук // Здобутки клініч. і експерим. медицини. 2010. - № 1. - С. 100-104.

11. Волощук О. Н. Энзиматическая активность компонентов системы энергообеспечения митохондрий лейкоцитов крови в динамике роста карциномы Герена / О. Н. Волощук, М. М. Марченко // Сибир. онкол. журн. - 2013. - № 6 (60). - С. 36-39.

12. Ещенко Н. Д. Определение количества янтарной кислоты и активности сукцинатдегидрогеназы. Методы биохимических исследований (липидный и энергетический обмен) / Н. Д. Ещенко, Г. Г. Вольский. Л. : Изд-во Ленинград ун-та., 1982. - С. 207-212.

13. Кривченкова Р. С. Определение активности цитохромоксидазы в суспензии митохондрий / Р. С. Кривченкова // Современные методы в биохимии / под ред. В. Н. Ореховича. - М. : Медицина, 1977. - С. 47-49.

14. Механизмы апоптоза лимсоцитов при клещевом энцефалите / О. Е. Чечина, Н.В.Рязанцева, Е. В. Сазонова [и др.] // Бюлл. сибир. медицины. 2011. - № 6. - C. 61-66.

15. Волощук О. М. НАДН-дегідрогеназна активність лейкоцитів крові щурів 3 трансплантованою карциномою Герена в динаміці онкогенезу / О. М. Волощук, М. М. Марченко, Е. О. Ференчук // Біологічні системи. Наук. вісн. Чернівецького ун-ту. -2012. - Т. 4, вип. 4. - С. 363-366.

16. Білюк А. Активність цитохромоксидази та сукцинатдегідрогенази в первинній культурі перещеплюваної карциноми легень Льюїс на різних етапах росту пухлини / А. Білюк, А. Негеля, Л. Гарманчук // Вісн. Київ. нац. ун-ту імені Тараса Шевченка. -2016. № 2 (21). - С. 81-85.

17. Энергетический и азотистый обмен ychlorella vulgaris beij. (chlorophyta) под влиянием селенита натрия / О. В. Василенко, О. И. Боднар, Г. Б. Винярская [и др.] // Альгология. - 2014. - № 24 (3). - С. 297-301.

18. Thyroid hormones enhance mitochondrial function in human epidermis / S. Vidali, J. Cheret, M. Giesen, S. Haeger, M. Alam // J Invest Dermatol. - 2016. 136 (10). - P. 2003-2012.

19. Алимова И. Л. Нарушения клеточного энергообмена при заболеваниях эндокринной системы у детей / И. Л. Алимова, Т. М. Романкова, В. С. Сухоруков // Росс. вестн. перинатологии и педиатрии. 2012. - № 4 (2). - С. 94-98.

20. Регуляторная роль митохондриальной дисфункции при гипоксии и ее взаимодействие с транскрипционной активностью / Л. Д. Лукьянова, А. М. Дудченко, Т. А. Цыбина, Э. Л. Германова // Вестн. Pocc. AMH. - 2007. - № 2. - C. 3-10.

21. Лобырева О. В. Тиреоидный статус и его влияние на активность окислительных ферментов / О. В. Лобырева // Медицина и здравоохранение. 2010. - № 201. - C. 259-263.

22. Овсепян Л. М. Роль активных фрорм кислорода в митохондриях / Л. М. Овсепян, Г. С. Казарян, Г. В. Захарян // Мед. наука Армении НАН РА. - 2009. № 2. - C. 3-10.

23. Wang $X$. The expanding role of mitochondria in apoptosis / X. Wang // Genes Dev. - 2001. - 15, No. 22. P. 2922-2933.

24. Марущак М. І. Мітохондріальні механізми апоптозу при гострому ушкодженні легень в експерименті / М. І. Марущак // Вісн. наук. дослідж. - 2017. № 1. - C. 121-124. 
25. Криницька І. Я. Роль активних форм кисню у розвитку гепатопульмонального синдрому в експерименті / І. Я. Криницька // Здобутки клініч. і експерим. медицини. - 2012. - № 1. - С. 72-76.

26. Circu M. L. Reactive oxygen species, cellular redox systems, and apoptosis / M. L. Circu, T. Y. Aw // Free Radic. Biol. Med. - 2010. - 48. - P. 749-762.

27. Криницька І. Я. Рівень апоптично та некротично змінених моноцитів та альвеолярних макрофрагів за умови експериментального гепатопульмонального синдрому / І. Я. Криницька // Світ медицини та біологiї. - 2013. - № 2. - С. 46-49.

\section{REFERENCES}

1. Sakvarelidze, I. (2014). Rol svobodno-radikalnogo okisleniya i antioksidantnoy zashchity $v$ razvitii vospalitelnykh protsessov $v$ parodonte $v$ zhenskoy populyatsii [The role of free radical oxidation and antioxidant protection in the development of inflammatory processes in the periodontium in the female population]. Aktualnye voprosy zhenskogo Zdorovya - Topical Women's Health Issues, 5, 64-76 [in Russian].

2. Uspenskaya, O.A. (2017). Izmeneniya biokhimicheskikh pokazateley krovi pri lechenii bystroprogressiruyushchego parodontita [Changes in blood biochemical parameters in the treatment of rapidly progressive periodontitis]. Problemy stomatologii - Dental Problems, 13 (2), 33-38 [in Russian].

3. Saveleva, N.N. (2015). Sostoyanie sistemy perekisnogo okisleniya lipidov i antioksidantnoy zashchity u bolnykh khronicheskim generalizovannym parodontitom I-II stepeni tyazhesti, sochetayushchegosya s parazitozami [The state of the system of lipid peroxidation and antioxidant protection in patients with chronic generalized periodontitis I-II severity, combined with parasitosis]. Journal of Education, Health and Sport, 5 (12), 465-476 [in Russian].

4. Almerich-Silla, J.M., Montiel-Company, J.M., Pastor, S., Serrano, F., Puig-Silla, M. \& Dasi, F. (2015). Oxidative stress parameters in saliva and its association with periodontal disease and types of bacteria. Dis. Markers., Article ID 653537.

5. Lykhatskyi, P.H., Fira, L.S. \& Honskyi, Ya.I. (2017). Dynamika zmin markeriv bioenerhetychnykh protsesiv ta tsytolizu u shchuriv pislia urazhennia nitrytom natriiu na tli tiutiunovoi intoksykatsii [Dynamics of changes of markers of bioenergetic processes and cytolysis in rats after damage by sodium nitrite against the background of tobacco intoxication]. Visnyk problem biolohii i medytsyny - Bulletin of Biology and Medicine, 2 (136), 147-152 [in Ukrainian].

6. Rutska, A.V. \& Krynytska, I.Ya. (2018). The changes of bioenergetics processes in rats of different sex and age in case of tobacco smoke and monosodium glutamate affection. International Journal of Medicine and Medical Research, 2 (4), 79-86.

7. Moyseeva, E.G. (2008). Metabolycheskyy gomeostaz i imunnaya reaktivnost organizma $v$ dinamike vospaleniya $v$ tkanyakh parodonta [Metabolic homeostasis and immune reactivity of the organism in the dynamics of inflammation in periodontal tissues]. Extended abstract of Doctor's thesis. Sumy: SumSU [in Russian].
28. In hyperthyroid rats octylguanidine protects the heart from reperfusion damage / N. Pavon, A. Aranda, N. Garcia [et al.] // Endocrine. - 2009. - 35, No. 6. P. $158-165$

29. Wu S. Mitochondrial oxidative stress causes mitochondrial fragmentation via differential modulation of mitochondrial fission-fusion proteins / S. Wu, F. Zhou, Z. Zhang, D. Xing // FEBS J. - 2011. - 278. - P. 941-954.

30. Franco M. Pleiotropic effects of thyroid hormones: Learning from hypothyroidism / M. Franco, E. Chavez, O. Perez-Mendez // Journal of Thyroid Research. 2011. - 17 p. Article ID 321030

8. Ratushnenko, V.O. (2010). Funktsionalna rol tioldysulfidnoi systemy pry eksperymentalnomu hipo- i hipertyreozi [Functional role of thiol-disulphide system in experimental hypo- and hyperthyroidism]. Odeskyi medychnyi zhurnal - Odesa Medical Journal, 2 (118), 17-20 [in Ukrainian].

9. European convention for the protection of vertebrate animals used for experimental and other scientific purposes. (1986). Council of Europe. Strasbourg, 123, 52.

10. Neiko, Ye.M., Herych, P.R., Ostrovskyi, M.M. \& Tomashchuk, L.M. (2010). Kysenzalezhni funktsii fahotsytiv u khvorykh na khronichne obstruktyvne zakhvoriuvannia lehen [Oxygen dependent phagocyte function in patients with chronic obstructive pulmonary disease]. Zdobutky klinichnoi i eksperymentalnoi medytsyny Achievements of Clinical and Experimental Medicine, 1, 100-104 [in Ukrainian].

11. Voloshchuk, O.N. \& Marchenko, M.M. (2013). Enzimaticheskaya aktivnost komponentov sistemy energoobespecheniya mitokhondriy leykotsitov krovi v dinamike rosta kartsinomy Gerena [Enzymatic activity of the components of the energy supply system of mitochondria of blood leukocytes in the growth dynamics of Guerin's carcinoma]. Sibirskiy onkologicheskiy zhurnal Siberian Oncology Journal, 6 (60), 36-39 [in Russian].

12. Eshchenko, N.D. \& Volskiy, G.G. (1982). Opredelenie kolichestva yantarnoi kisloty i aktivnosti suktsinatdegidrogenazy. Metody biokhimicheskikh issledovaniy (lipidnyy i energeticheskiy obmen) [Determination of the amount of succinic acid and succinate dehydrogenase activity. Methods of biochemical research (lipid and energy metabolism)]. Leningrad: Leningrad University Publishing House, 207-212 [in Russian].

13. Krivchenkova, R.S. (1977). Opredelenie aktivnosti tsitokhromoksidazy v suspenzii mitokhondrii. Sovremennye metody v biokhimii [Determination of cytochrome oxidase activity in mitochondrial suspension. Modern methods in biochemistry]. Orekhovich, V.N., \& Krivchenkova, R.S. (Eds.). Moscow: Meditsina [in Russian].

14. Chechina, O.E., Ryazantseva, N.V., \& Sazonova, E.V. (2011). Mekhanizmy apoptoza limfotsitov pri kleshchevom entsefalite [Mechanisms of lymphocyte apoptosis in tick-borne encephalitis]. Byulleten sibirskoy meditsiny - Bulletin of Siberian Medicine, 6, 61-66 [in Russian].

15. Voloshchuk, O.M., Marchenko, M.M., \& Ferenchuk, E.O. (2012). NADN-dehidrohenazna aktyvnist leikotsytiv krovi shchuriv z transplantovanoiu kartsyno- 
moiu herena $v$ dynamitsi onkohenezu [NADN-dehydrogenase activity of leukocyte blood in rats with transgenic carcinoma of the heron in the dynamics of oncogenesis]. Naukovyi visnyk Chernivetskoho universytetu. Biolohiia (Biolohichni systemy) - Scientific Herald of Chernivtsi University. Biology (Biological Systems), 4 (4), 363-366 [in Ukrainian].

16. Biliuk, A., Nehelia, A. \& Harmanchuk, L. (2016). Aktyvnist tsytokhromoksydazy ta suktsynatdehidrohenazy v pervynnii kulturi pereshchepliuvanoi kartsynomy lehen Liuis na riznykh etapakh rostu pukhlyny [The activity of cytochrome oxidase and succinate dehydrogenase in the primary culture of Lewis lung transfusion carcinoma at different stages of tumor growth]. Visnyk Kyivskoho natsionalnoho universytetu imeni Tarasa Shevchenka Bulletin of the Taras Shevchenko National University of Kyiv, 2 (21), 81-85 [in Ukrainian].

17. Vasilenko, O.V., Bodnar, O.I., Viniarskaya, G.B., Sinyuk, Yu.V. \& Grubinko, V.V. (2014). Energeticheskiy i azotistyy obmen uchlorella vulgaris beij. (chlorophyta) pod vliyaniem selenita natriya [Energy and nitrogen metabolism of uchlorella vulgaris beij. (chlorophyta) under the influence of sodium selenite]. Algologiya - Algology, 24 (3), 297-301 [in Russian].

18. Vidali, S., Cheret, J., Giesen, M., Haeger, S., \& Alam, M. (2016). Thyroid hormones enhance mitochondrial function in human epidermis. J. Invest. Dermatol., 136 (10), 2003-2012.

19. Alimova, I.L., Romankova, T.M. \& Sukhorukov, V.S. (2012). Narusheniya kletochnogo energoobmena pri zabolevaniyakh endokrinnoy sistemy u detey [Disorders of cellular energy metabolism in endocrine diseases in children]. Rossiiskiy vestnik perinatologii i pediatrii-Russian Bulletin of Perinatology and Pediatrics, 4 (2), 94-98 [in Russian].

20. Lukyanova, L.D., Dudchenko, A.M., Tsybina, T.A., \& Germanova, E.L. (2007). Regulyatornaya rol mitokhondrialnoy disfunktsii pri gipoksii i yeye vzaimodeystviye $s$ transkriptsionnoy aktivnostyu [The regulatory role of mitochondrial dysfunction during hypoxia and its interaction with transcriptional activity]. Vestnik Rossiyskoy AMN - Bulletin of Russian AMS, 2, 3-10 [in Russian].

21. Lobyreva, O.V. (2010). Tireoidnyi status i ego vliyanie na aktivnost okislitelnykh fermentov [Thyroid status and its effect on the activity of oxidative enzymes].
Meditsina i zdravookhraneniye - Medicine and Health Care, 201, 259-263 [in Russian].

22. Ovsepyan, L.M., Kazaryan, G.S. \&Zakharyan, G.V. (2009). Rol aktivnykh form kisloroda $v$ mitokhondriiakh [The role of reactive oxygen species in mitochondria]. Meditsinskaya nauka Armenii NAN RA-Medical Science of Armenia NAS RA, 2, 3-10 [in Russian].

23. Wang, $X$. (2001). The expanding role of mitochondria in apoptosis. Genes Dev., 15, 22, 2922-2933.

24. Marushchak, M.I. (2017). Mitokhondrialni mekhanizmy apoptozu pry hostromu ushkodzhenni lehen $v$ eksperymenti [Mitochondrial mechanisms of apoptosis in acute lung injury in the experiment]. Visnyk naukovykh doslidzhen - Bulletin of Scientific Research, 1, 121-124 [in Ukrainian].

25. Krynytska, I.Ya. (2012). Rol aktyvnykh form kysniu u rozvytku hepatopulmonalnoho syndromu $v$ eksperymenti [The role of reactive oxygen species in the development of hepatopulmonary syndrome in the experiment]. Zdobutky klinichnoi i eksperymentalnoi medytsyny - Achievements of Clinical and Experimental Medicine, 1, 72-76 [in Ukrainian].

26. Circu, M.L. \& Aw T.Y. (2010). Reactive oxygen species, cellular redox systems, and apoptosis. Free Radic. Biol. Med., 48, 749-762.

27. Krynytska, I.Ya. (2013). Riven apoptychno ta nekrotychno zminenykh monotsytiv ta alveoliarnykh makrofahiv za umovy eksperymentalnoho hepatopulmonalnoho syndromu [Level of apoptotic and necrotizing altered monocytes and alveolar macrophages under experimental hepatopulmonary syndrome]. Svit medytsyny ta biolohii - World of Medicine and Biology, 2, 46-49 [in Ukrainian].

28. Pavon, N., Aranda, A., Garcıa, N., HernandezEsquivel, L., \& Chavez, E. (2009). In hyperthyroid rats octylguanidine protects the heart from reperfusion damage. Endocrine, 35, 6, 158-165.

29. Wu, S., Zhou, F., Zhang, Z. \& Xing, D. (2011). Mitochondrial oxidative stress causes mitochondrial fragmentation via differential modulation of mitochondrial fission-fusion proteins. FEBS J., 278, 941-954.

30. Franco, M., Chavez, E., \& Perez-Mendez, O. (2011). Pleiotropic effects of thyroid hormones: Learning from hypothyroidism. Journal of Thyroid Research, 17. Article ID 321030.

В. В. Щерба, Т. Я. Ярошенко, И. А. Бандас, М. М. Корда ТЕРНОПОЛЬСКИЙ НАЦИОНАЛЬНЫЙ МЕДИЦИНСКИЙ УНИВЕРСИТЕТ ИМЕНИ И. Я. ГОРБАЧЕВСКОГО МОЗ УКРАИНЫ

\section{ИЗМЕНЕНИЯ ПРОЦЕССОВ ЭНЕРГООБЕСПЕЧЕНИЯ НЕЙТРОФИЛОВ КРОВИ У КРЫС С ПАРОДОНТИТОМ НА ФОНЕ ГИПЕР- И ГИПОТИРЕОЗА}

Резюме

Вступление. Воспалительные заболевания пародонта являются одной из наиболее актуальных проблем стоматологии, которые имеют социальную значимость. Наряду с известными концепциями их 
патогенеза значительное внимание уделяют активации перекисного окисления липидов, которое может нарушать окисление субстратов дегидрогеназами и транспорт электронов по дыхательной цепи, вызывая разъединение дыхания и окислительного фросфорилирования.

Цель исследования - изучить прочессы энергообеспечения нейтрофилов крови у крыс с пародонтитом без сопутствующей патологии и на фроне гипер- и гипотиреоза.

Методы исследования. Исследование проведено на белых крысах-самцах, у которых моделировали пародонтит, пародонтит на фроне гипертиреоза и пародонтит на фроне гипотиреоза. В митохондриальной фрракции популяции нейтрофрилов крови определяли сукцинатдегидрогеназную и цитохромоксидазную активность. Количество нейтрофилов крови с пониженным трансмембранным митохондриальным потенциалом устанавливали методом проточной цитофрлуориметрии с помощью набора реактивов "MitoScreen" ("BD Pharmigen", США).

Результаты и обсуждение. Сукцинатдегидрогеназная активность в митохондриях нейтрофрилов крови крыс с смоделированным пародонтитом уменьшилась на 16,3 \% (p<0,001), с смоделированным пародонтитом на фроне гипертиреоза - на 40 \% (р<0,001), с смоделированным пародонтитом на фроне гипотиреоза - на 26,7 \% (p<0,001) относительно контрольной группы. Что касается конечного энзима дыхательной цепи митохондрий - цитохромоксидазы, то при пародонтите без сопутствующей патологии его активность в митохондриях нейтрофрилов крови животных достоверно не изменилась. Экспериментальный пародонтит на фоне гипертиреоза сопровождался снижением цитохромоксидазной активности на 15,2 \% (p<0,01), а у гипотиреоидных крыс - на 16,2 \% $(p<0,001)$ относительно контрольной группы. Исследование митохондриального трансмембранного потенциала $\left(\Delta \Psi_{\mathrm{m}}\right)$ нейтрофилов крови показало, что у животных с смоделированным пародонтитом процент нейтрофрилов крови с уменьшенным $\triangle \Psi$ т увеличился на 51,6 \% ( $p<0,001)$, с смоделированным пародонтитом на фроне гипертиреоза - 8 $2,4$ раза ( $p<0,001)$, с смоделированным пародонтитом на фроне гипотиреоза - в 1,8 раза $(p<0,001)$ относительно контрольной группы.

Вывод. Моделирование пародонтита на фроне тиреоидной дисфрункции сопровождается достоверным ингибированием процессов энергообеспечивающего окисления, на что указывает снижение сукцинатдегидрогеназной и цитохромоксидазной активности в митохондриях нейтрофилов крови как при гипертиреозе, так и при гипотиреозе.

КЛЮЧЕВЫЕ СЛОВА: пародонтит; энергообеспечивающее окисление; тиреоидная дисфункция.

V. V. Shcherba, T. Ya. Yaroshenko, I. A. Bandas, M. M. Korda I. HORBACHEVSKY TERNOPIL NATIONAL MEDICAL UNIVERSITY

\section{CHANGES IN THE PROCESSES OF ENERGY PROVIDING OF NEUTROPHILS IN RATS WITH PERIODONTITIS ON THE BACKGROUND OF HYPER- AND HYPOTHYROIDISM}

\section{Summary}

Introduction. Inflammatory periodontal diseases are one of the most urgent problems of dentistry that have social significance. Along with the known concepts of their pathogenesis, considerable attention is paid to the activation of peroxide oxidation of lipids, which may interfere with the oxidation of substrates with dehydrogenases and the transport of electrons along the respiratory chain, causing the separation of respiration and oxidative phosphorylation.

The aim of the study - to investigate the processes of energy providing of neutrophils in rats with periodontitis without comorbidities and against the background of hyper- and hypothyroidism.

Research Methods. The study was performed on white male rats, in which periodontitis, periodontitis on the background of hyperthyroidism and periodontitis on the background of hypothyroidism were modeled. In the mitochondrial fraction of the neutrophils population, the succinate dehydrogenase and cytochrome oxidase activity were determined. The number of blood neutrophils with reduced transmembrane mitochondrial potential was determined by flow cytometry using a set of MitoScreen reagents (BD Pharmigen, USA).

Results and Discussion. Succinate dehydrogenase activity in mitochondria of neutrophils of rats with simulated periodontitis decreased by $16.3 \%(p<0.001)$, with simulated periodontitis on the background of hyperthyroidism by $40 \%$ (p<0.001), with a periodontitis simulated with hypothyroidism - by $26.7 \%(p<0.001)$ vs the index of the control group. Concerning end-stage enzyme of the respiratory chain of mitochondria - cytochrome oxidase, under 
the condition of periodontitis without concomitant pathology, the activity of enzyme in mitochondria of rat neutrophils significantly did not change. Experimental periodontitis on the background of hyperthyroidism is accompanied by a decrease in cytochrome oxidase activity by $15.2 \%(p<0.01)$, and in hypothyroidic rats - by $16.2 \%(p<0.001)$ vs the control group. Investigation of mitochondrial transmembrane potential $\left(\Delta \psi_{\mathrm{m}}\right)$ of blood neutrophils showed that in rats with simulated periodontitis, the percentage of blood neutrophils with reduced $\Delta \Psi_{m}$ increased by $51.6 \%$ $(p<0.001)$, with simulated periodontitis in the background of hyperthyroidism -2.4 times $(p<0.001)$, with the simulated periodontitis in the hypothyroidism background -1.8 times $(p<0.001)$ vs the control group.

Conclusion. Modeling periodontitis against a background of thyroid dysfunction is accompanied by a possible inhibition of processes of energy-supplying oxidation, as indicated by decreasing succinate dehydrogenase and cytochrome oxidase activity in mitochondria of blood neutrophils, both under conditions of hyperthyroidism and hypothyroid conditions.

\section{KEY WORDS: periodontitis; energy-supplying oxidation; thyroid dysfunction.}

Адреса для листування: В. В. Щерба, Тернопільський національний медичний університет імені І. Я. Горбачевського МОз України, майдан Волі, 1, Тернопіль, 46001, Україна, e-mail: shcherba@tdmu.edu.uа. 